\title{
ANALYSES OF SKIN LESION AREAS AFTER THRESHOLDING
}

\author{
Magdalena Michalska \\ Lublin University of Technology, Department of Electronics and Information Technology, Lublin, Poland
}

Abstract. Melanoma is one of the fastest spreading cancers. The aim of the article is to segment the skin lesions from human skin dermatoscopic images covered by melanoma. Threshold segmentation was used, which allows a single skin lesion to be analyzed. It shows the four areas of each based on their color. The created software monitors the border of skin lesion areas. Segmentation and analysis of the resulting images with different areas of skin change was carried out in the Matlab software.

Keywords: dermatoscopy, melanoma, thresholding, image region analysis

\section{ANALIZA OBSZARÓW ZMIAN SKÓRNYCH PO SEGMENTACJI PRZEZ PROGOWANIE}

Streszczenie. Czerniak to jeden z najszybciej rozprzestrzeniajacych sie nowotworów. Celem artykułu jest segmentacja zmiany skórnej z obrazów dermatoskopowych ludzkiej skóry objętych czerniakiem. Użyto segmentacj przez progowanie, która pozwala na analizę pojedyńczej zmiany skórnej. Ukazuje cztery obszary każdej z nich w oparciu o ich barwę. Stworzone oprogramowanie monitoruje granice obszarów zmiany skórnej. Segmentacja i analiza powstałych obrazów z różnymi obszarami zmiany skórnej została przeprowadzona w środowisku Matlab.

Slowa kluczowe dermatoskopia, czerniak, segmentacja przez progowanie, analiza regionów obrazu

\section{Introduction}

Global warming through sunlight can lead to an increase in skin cancer cases. Melanoma is one of the fastest growing cancers among the world's population of fair-skinned people. However, its early diagnosis can lead to effective, life-saving treatment. Dermatoscopy seems to be a complicated and obscure technique for beginners. This non-invasive imaging technique provides many features of skin lesions. Skin images are subjected to a dermatologist's analysis. However, when they are inexperienced, the cancer may not be diagnosed. Therefore, the development of an effective computerized diagnostic process in the diagnosis of skin cancers is needed. The article briefly presents methods for assessing dermatoscopic images, segmentation methods based on thresholding and analyses of melanoma images based on regions.

\section{Fundamentals of clinical diagnostics}

\subsection{Dermatoscopy}

In the last decade, many researchers have dealt with changes in human skin. If its malignant variety is diagnosed in the early stages, a much larger percentage of patients can be cured. Many techniques have been developed to detect the border of skin lesions on dermatoscopic images. Dermatoscopy is an imaging technique that shows the many features of skin lesions. The resulting skin images are subjected to a dermatologist's analysis.

The primary goal of dermoscopic examination is differential diagnosis of pigmented lesions divided into melanocytic and nonmelanocytic lesions. It is then possible to isolate melanocytic lesions requiring surgical excision. The skin segment taken at that time is subjected to histopathological examination. Atypical moles, melanomas, basal cell carcinoma of the skin, benign moles, histiocytomas, hemangiomas and seborrheic warts are then defined. The advantages of dermatoscopic examination are its greater diagnostic sensitivity compared to looking at birthmarks with the naked eye. This enables more accurate examination of skin lesions and avoids unnecessary skin biopsies in cases difficult to assess with the naked eye. Scoring systems cannot be used for some specific locations such as the face, mucous membranes, hands or soles of the feet as they do not provide reasonable results.

This means that these methods are not sufficient in these locations. Therefore, the development of a computerized diagnostic process is extremely beneficial for the diagnosis of skin cancers $[19,20,21]$. The developed methods for transforming dermatoscopic images include splitting the original image into regions. Image analysis based on computer systems monitors the boundaries of skin lesions.

\subsection{Image assessment methods}

Many methods have been adopted that allow a dermatologist to evaluate a skin change for skin melanoma. These include scales developed by doctors to characterize the dermatological traits under examination: classical pattern analysis, $\mathrm{ABCD}$ scale (sometimes extended to ABCDE form), CASH algorithm, Hunter scale, Clark and Breslow scale, TNM scale, list of 3 points, list of 7 points, Menzies method, and Chaos and Clues.

The pattern analysis method is used to assess pigmented skin eruptions. The natural skin color (different for each person) is often the reference point in the process of analyzing the colors of the birthmark. Dye efflorescence usually consists of more than one color, which can make it difficult for the human eye to distinguish colors.

The ABCD (E) scale is used by doctors when diagnosing melanoma. On its basis, it is possible to calculate the TDS (Total Dermatoscopy Score) determining whether the test mark has features of melanoma [28].

$$
T D S=1.3 \times A+0.1 \times B+0.5 \times C+0.5 \times D
$$

where $A$ (asymmetry) - melanoma is asymmetrical about each axis, unlike benign lesions; $B$ (borders) - edges are uneven and jagged; $C$ (color) - light brown to black, $D$ (diameter) diameter $>5 \mathrm{~mm}$ or (dynamics) dynamics of morphological changes in the tumor; in the extended version E (elevate) - convex change over the surrounding epidermis.

The Glasgow scale is considered to be a set of clinical signs of locally developed melanoma [6]. The CASH algorithm (Color, Architecture, Symmetry, Homogeneity) has comparable sensitivity with slightly greater specificity. The indicators of the effectiveness of doctors include specificity and sensitivity [12].

MoleMate allows a preliminary diagnosis to be performed semi-automatically to assess the skin change. In addition, next to the descriptions of birthmarks, additional photos appear to simplify the process. It is a useful tool for classifying features such as birthmark size, hemoglobin accumulation, infiltration, individual blood vessels, and significant collagen and hemoglobin deficiencies [9]. The Clark [8] and Breslow [2] scales determine the extent of infiltration of lesions into the depths. There are four levels of infiltration on the Breslow scale. The degrees correspond to the depth of infiltration expressed in millimeters. The higher the grade, the worse the prognosis.

In dermoscopic examination, in addition to analyzing the pattern of pigmented lesions, dermoscopic diagnostic algorithms (7-point rule, 3-point rule), Menzies principle, and evaluation of the total dermoscopic examination index (TDS) are used. It is believed that the approach to the diagnosis of nevi and melanoma should be adapted to the clinical data and the macroscopic appearance of the lesion, therefore the assessment methods are constantly being modified [1, 17, 29, 30]. 


\section{Thresholding}

The goal of many projects is to create a semi-automatic and automatic computer system that allows you to take pictures of skin lesions and then subject them to individual analysis [22, 24-26]. The available versions of the diagnostic programs still improve the effectiveness of early melanoma detection.

The image pre-processing method is primarily used to remove unwanted artifacts from clinical dermatoscopic images. Color analysis is one of the basic elements for a dermatologist in the initial diagnosis of melanoma. It concerns the change of color, shape and texture of the skin change on the patient's body $[3,11$, 15]. In [15], the background from the dermatoscopic image was segmented using the last peak on a gray scale image histogram. It is found and the 90th percentile of its location is selected as the threshold. The images are then qualified using different classifiers as those representing a cancer-endangered lesion or those showing only healthy tissue.

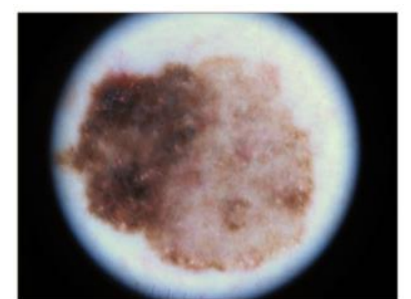

a)

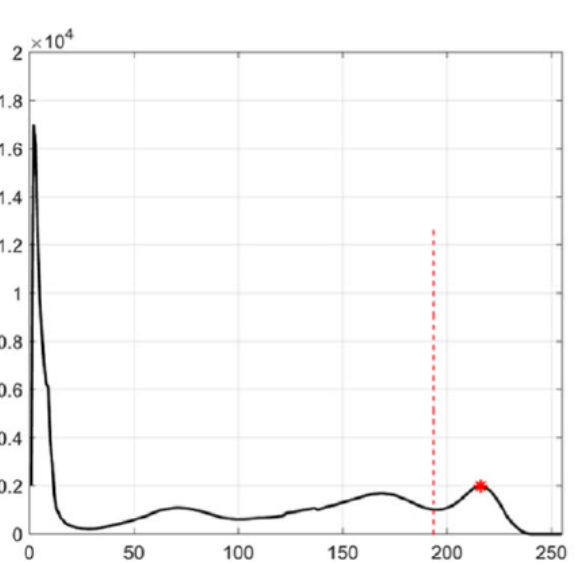

b)

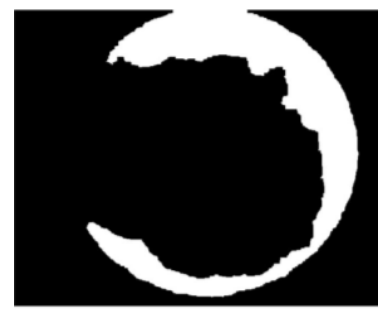

c)

Fig. 1. Pseudo-background region segmentation: (a) original image, (b) histogram of the gray image, (c) thresholded and processed mask of background [15]

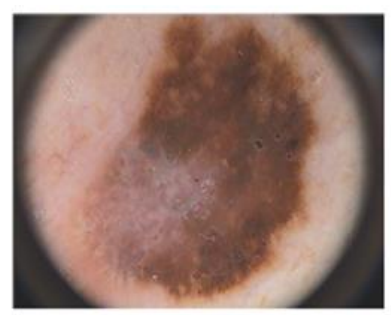

a)

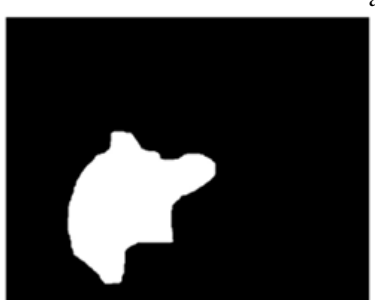

b)

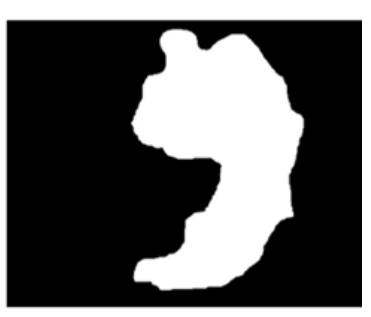

c)
Fig. 2. Obtained new skin lesion regions: (a) original image, (b) middle part of the lesion, (c) dark brown area of the lesion [23]

For the general data set, there are images containing other objects in their marginal areas, some ranges of damage reach the image boundaries. Figure 2 shows an example of using segmentation based on thresholding [23]. It uses the selected intensity value threshold to separate the skin change from the background of the patient's light skin. In dermoscopy, the healthy skin around the lesion can be taken as the background, but the background must be correctly determined. Threshold segmentation was also used in $[4,27]$.

\section{Materials and methods}

Two dermatoscopic image databases were used in the article: ISIC (The International Skin Imaging Collaboration) [8] and DermIS (Dermatology Information System) [7]. These are public databases of clinical dermoscopic images of skin lesions. Melanoma can spread by satellite lesions, or extend via the lymphatics or blood stream. This means it can appear everywhere in the body, especially the lungs, liver, brain, skin and bones. From the databases 20 patient images were selected in which malignant melanoma was guided. The results of the tests were confirmed by histopathological examination of the lesion.

In the process of pre-processing dermatoscopic images, special attention is paid to the artifacts created during the imaging process. Their removal is of particular importance in the process of further image processing. Dermatoscopic images often contain some artifacts that are an obstacle to identifying skin lesions from healthy skin $[14,18]$. The artifacts include the patient's hair present on the dermatoscopic image, large blood vessels, skin lines, hematomas, vesicles under the skin, markers of lesions and scars on the skin. Automatic programs such as DullRazor [16] and VirtualShave [10] are frequently used.

To avoid the difficult stage of releasing artifacts in the images. Dermatoscopic images of light skin were used, free of dark and thick hair in the area of the melanoma. Threshold segmentation was used for the process of segmentation of selected areas of the skin lesions with diagnosed melanoma. One or two thresholds were included in the algorithm. The areas segmented in the image contain pixels below a given threshold, above it, and within a selected range. The areas obtained in the resulting images were analyzed using the measured properties of the image regions by functions in Matlab: bwarea (estimates the area of the objects in an image), Sum(sum)e, and BwEuler (calculate the Euler number for the binary segmented image) [13].

\section{Results}

Color images were converted into grayscale images, and their normalized histograms were also determined. The received images had intensity values in the range of 1-256. For each patient, four optimal areas were distinguished, differing in the value of pixel intensity, which corresponded to visible changes in the color of the melanomamark. Values less than 45, between 55-100, between 115-130 and less than 150 were selected. Figures 3 and 4 show the results of segmentation for 2 of selected patients. The results of binarization with an upper threshold are shown in Figure $3 \mathrm{~b}$ and Figure $4 \mathrm{~b}$, and binarization with a lower threshold of 150 in Figure $3 \mathrm{e}$ and Figure 4e. Areas of skin lesions obstructing pixels from 55 to 100 for each of the patients are in Figure $3 \mathrm{c}$ and Figure 4c. Melanoma is characterized by color changes inside the lesion. Areas of a similar color accumulating side-by-side form the clusters of cells.

The values of the bwarea, Sum(sum)e, and bwEuler functions were calculated, and are listed in Table 1 for the four segmented areas. The results are presented for five selected patients. Each of the images obtained after segmentation selected from four areas has different values. In addition, the entire skin lesion was segmented using image intensities above 150. Larger segmented elements in the resulting images have higher values from Table 1 than other segmented areas. The values allow you to assess the size of the segmented area. In most skin lesions, the darkest area of the lesion (with pixel intensity values below 45) covers the smallest part of the image. The area covering the skin lesion melanoma with pixels in the range of 115-130 mostly shows the border between the lesion and healthy tissue. 

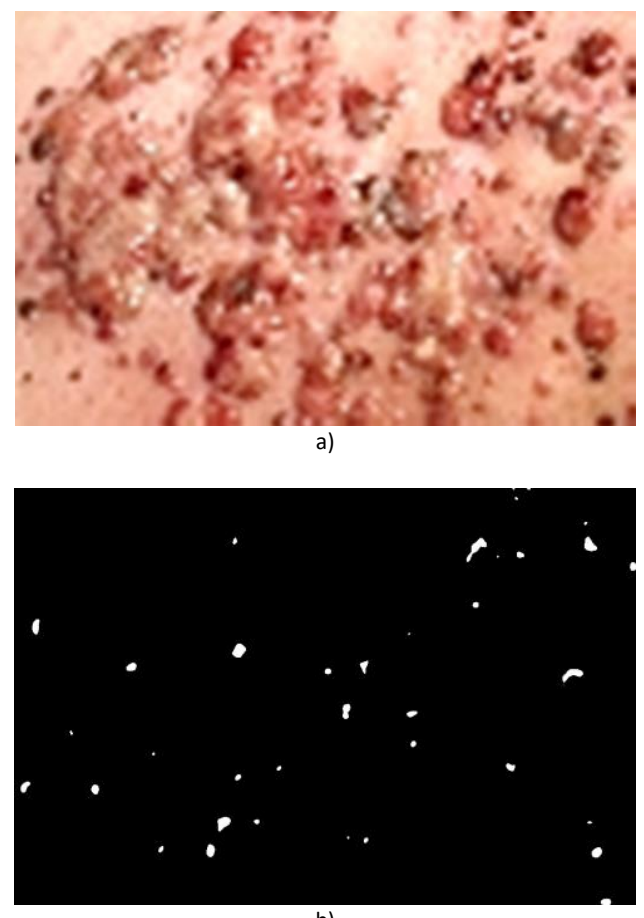

b)
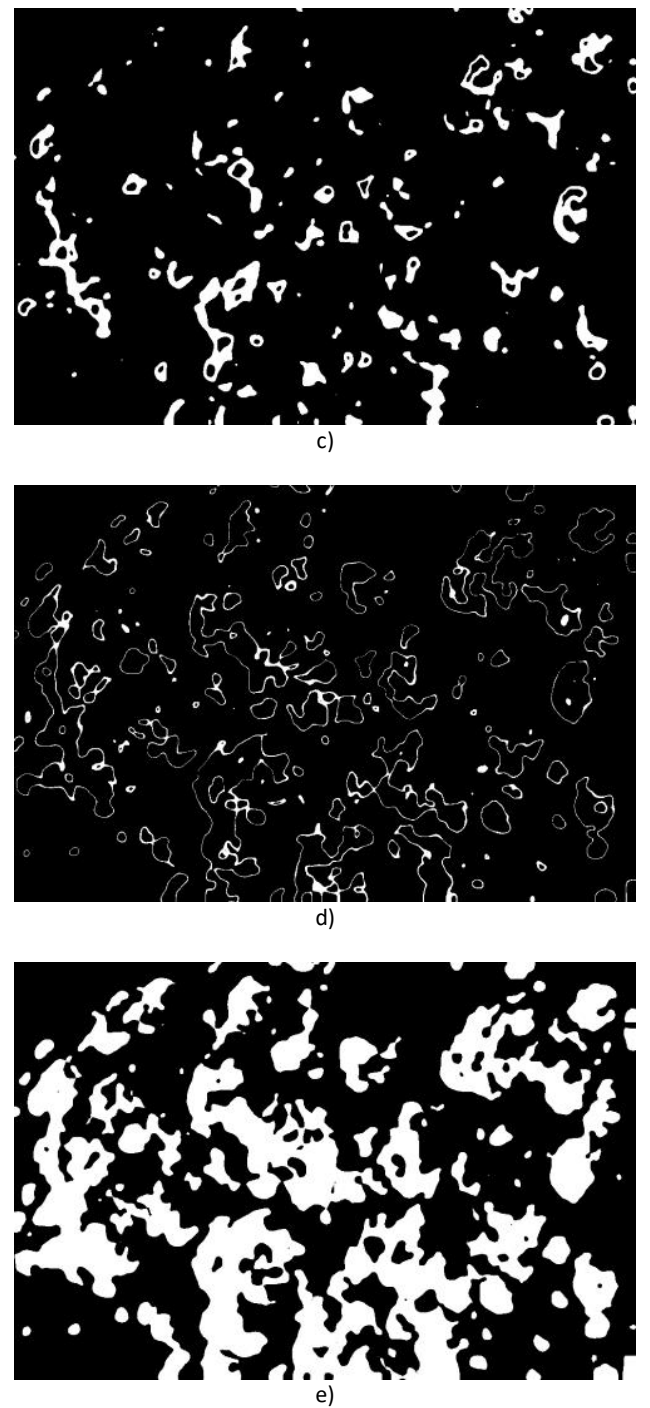

Fig. 3. a) Original dermatoscopic color image - patient 1 ; b) segmented image with a threshold below 45; c) segmented image with 55-100 pixels; d) segmented image with pixels of 115-130, e) segmented image with pixels of less than 150
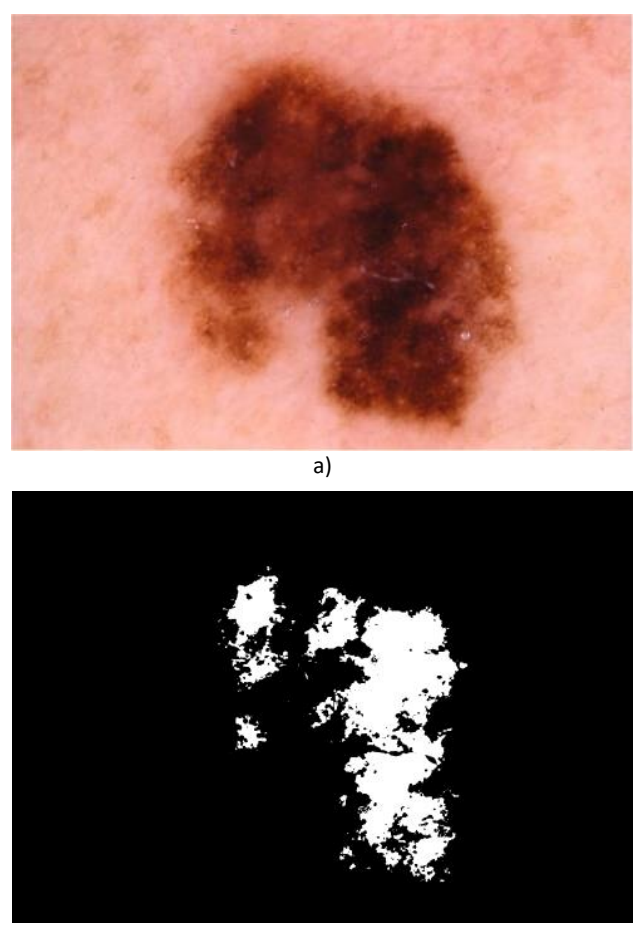

b)

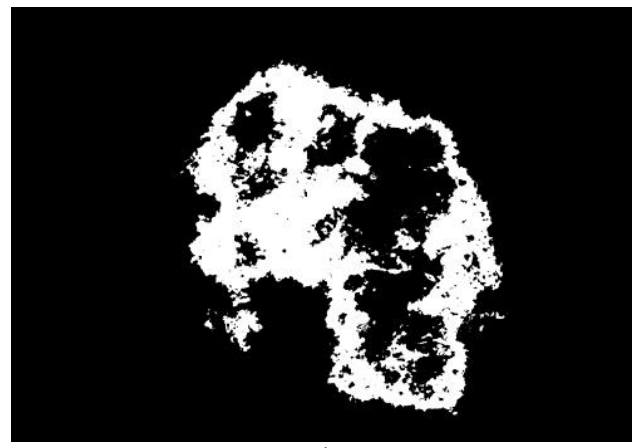

c)

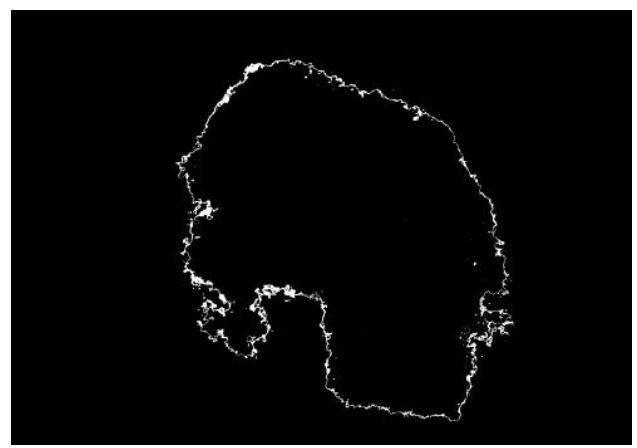

d)

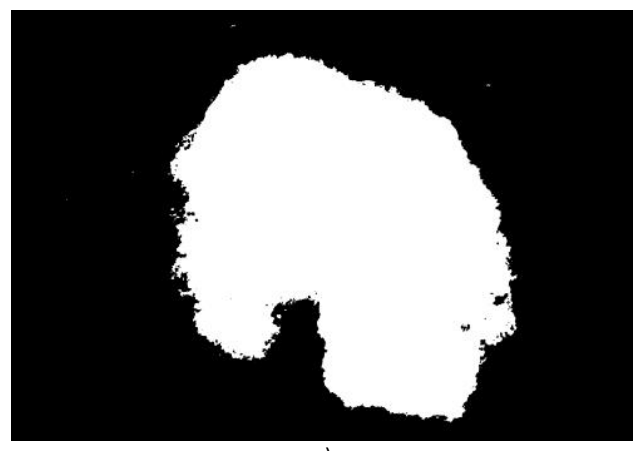

e)

Fig. 4. a) Original dermatoscopic color image - patient 5; b) segmented image with a threshold below $45 ; c)$ segmented image with $55-100$ pixels; d) segmented image with pixels of 115-130, e) segmented image with pixels of less than 150 
Table 1. Values of the region analysis function for segmented skin lesion areas for 5 selected patients

\begin{tabular}{|c|c|c|c|c|}
\hline \multirow{2}{*}{ 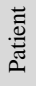 } & \multirow{2}{*}{ Region } & \multicolumn{3}{|c|}{ Functions } \\
\hline & & BwEuler & Sum(sum)e & bwarea \\
\hline \multirow{4}{*}{1} & $>45$ & 285 & 361 & $3.6650 \mathrm{e}+02$ \\
\hline & $55-100$ & 2023 & 2642 & $2.6769 \mathrm{e}+03$ \\
\hline & $115-130$ & 4912 & 6044 & $6.1186 \mathrm{e}+03$ \\
\hline & $<150$ & 3181 & 4232 & $4.2869 \mathrm{e}+03$ \\
\hline \multirow{4}{*}{2} & $>45$ & 1580 & 2018 & $2.0423 \mathrm{e}+03$ \\
\hline & $55-100$ & 4119 & 5213 & $5.2805 \mathrm{e}+03$ \\
\hline & $115-130$ & 6684 & 8139 & $8.2535 \mathrm{e}+03$ \\
\hline & $<150$ & 2744 & 3428 & $3.4743 e+03$ \\
\hline \multirow{4}{*}{3} & $>45$ & 2627 & 3109 & $3.1591 \mathrm{e}+03$ \\
\hline & $55-100$ & 7076 & 8140 & $8.2598 \mathrm{e}+03$ \\
\hline & $115-130$ & 7208 & 8310 & $8.4234 \mathrm{e}+03$ \\
\hline & $<150$ & 7208 & 8310 & $8.4234 \mathrm{e}+03$ \\
\hline \multirow{4}{*}{4} & $>45$ & 924 & 1275 & $1.2911 \mathrm{e}+03$ \\
\hline & 55-100 & 2159 & 2966 & $3.0001 \mathrm{e}+03$ \\
\hline & $115-130$ & 2852 & 4144 & $4.1961 \mathrm{e}+03$ \\
\hline & $<150$ & 1532 & 2094 & $2.1221 \mathrm{e}+03$ \\
\hline \multirow{4}{*}{5} & $>45$ & 3115 & 5575 & $5.6365 \mathrm{e}+03$ \\
\hline & $55-100$ & 4918 & 7344 & $7.4399 \mathrm{e}+03$ \\
\hline & $115-130$ & 3213 & 4317 & $4.3751 \mathrm{e}+03$ \\
\hline & $<150$ & 1586 & 2235 & $2.2635 \mathrm{e}+03$ \\
\hline
\end{tabular}

\section{Conclusions}

Threshold-based methods include specifying one or more histogram threshold values that separate objects from the background. Region-based methods include grouping pixels into homogeneous regions using region merging, region division, or both. The area of the entire skin lesion has been divided into four smaller areas of different color that characterize it, making it possible to analyze the entire skin lesion more effectively.

The proposed algorithm for segmenting dermatoscopic images in Matlab allows four areas of the skin covered by malignant melanoma to be distinguished.

However, there are many problems with the segmentation process, which provides the ability to detect features and later classify skin lesions. Archiving the obtained images of birthmarks enables their comparison in time and the creation of the body maps.

Development of teledermoscopy, transmission of videodermoscopic images during teleconsultation increases the diagnostic possibilities.

\section{References}

[1] Argenziano G., Catricalà C., Ardigo M.: Seven-point checklist of dermoscopy revisited. The British Journal of Dermatology 4, 2011, 785-90.

[2] Breslow A.: Thickness, cross-sectional areas and depth of invasion in the prognosis of cutaneous melanoma. Annals of Surgery 172, 1970, 902-908.

[3] Celebi M. E., Kingravi H. A., Uddin B.: A methodological approach to the classification of dermoscopy images. Computerized Medical Imaging and Graphics 2007, 362-373

[4] Celebi M. E., Wen Q., Hwang S., Iyatomi H., Schaefer G.: Lesion border detection in dermoscopy images using ensembles of thresholding methods. Skin Res. Technol. 19 (1), 2013, 252-258.

[5] Clark W. H., From L., Bernardino E. A.: Histogenesis and biologic behavior of primary human malignant melanomas of the skin. Cancer Research 29, 1969, 705-726.

[6] Damilola A., Okuboyejo O.: Automating skin disease diagnosis using image classifications. Proceedings of the world congress on engineering and computer science II, San Francisco 2013.

[7] Dermatoscopy images database:

https://www.dermis.net/dermisroot/en/list/m/search.htm (accessed: 20.03.2020).

[8] Dermatoscopy images database:

https://www.isic-archive.com/ (accessed: 20.03.2020)
[9] Emery J. D, Hunter J., Hall P. N.: Accuracy of siascopy for pigmented skin lesions encountered in primary care: development and validation of a new diagnostic algorithm. BMC Dermatology 10, 2010, 1-9.

[10] Fiorese, M., Peserico, E., Silletti, A.: VirtualShave: automated hair removal from digital dermatoscopic image. Proc. IEEE EMBS, 2011, 5145-5148.

[11] Ganster H., Pinz A., R"ohrer R.: Automated melanoma recognition medical imaging. IEEE Transactions 20(3), 2001, 233-239.

[12] Henning J., Dusza S., Wang S.: The cash (color, architecture, symmetry, and homogeneity) algorithm for dermoscopy. Archives of Dermatology 56, 2007, $45-52$.

[13] https://www.mathworks.com/help/images/pixel-values-and-image-statistics.html (accessed: 20.03.2020)

[14] Huang, A., Kwan, S., Chang, W., Liu, M., Chi, M., Chen, G.: A robust hair segmentation and removal approach for clinical images of skin lesions. Proc. IEEE EMBS 2013, 3315-3318.

[15] Jahanifar M., Tajeddin N. Z., Mohammadzadeh Asl B., Gooya A.: Supervised saliency map driven segmentation of lesions in dermoscopic images. IEEE Journal of Biomedical and Health Informatics 23(2), 2019, 509-518.

[16] Kiani, K., Sharafat, A.R.: E-shaver: An improved dullrazor for digitally removing dark and light-colored hairs in dermoscopic images. Comput. Biol. Med. 41(3), 2011, 139-145.

[17] Kittler H., Riedl E., Rosendahl C.: Dermatoscopy of unpigmented lesions of the skin: a new classification of vessel morphology based on pattern analysis. Dermapathology. Practical and Conceptual 14, 2008, 3-7.

[18] Koehoorn J., Sobiecki A. C., Boda D., Diaconeasa A., Doshi S., Paisey S., Jalba A., Telea A.: Automated digital hair removal by threshold decomposition and morphological analysis. International Symposium on Mathematical Morphology and Its Applications to Signal and Image Processing 9082, 2015, $15-26$

[19] Korjakowska J. J.: Automatic detection of melanomas: An application based on the abcd criteria. Springer 7339, 2012, 67-76

[20] Korotkov K., Garcia R.: Computerized analysis of pigmented skin lesions: A review. Artificial Intelligence in Medicine 56(2), 2012, 69-90.

[21] Leo G. D., Paolillo A., Sommella P., G. Fabbrocini G., Rescigno O.: A software tool for the diagnosis of melanomas. IEEE Instrumentation and Measurement Technology Conference 2010, 886-891.

[22] Maglogiannis I., Pavlopoulos S., Koutsouris D.: An integrated computer supported acquisition, handling, and characterization system for pigmented skin lesions in dermatological images. IEEE Transactions on Information Technology in Biomedicine 2005, 86-98.

[23] Mendonca T., Ferreira P. M., Marques J. S., Marcal A. R., Rozeira J.: A dermoscopic image database for research and benchmarking. 35th Annual International Conference of the IEEE EMBS Osaka 2013, 5437-5440.

[24] Michalska M.: Przegląd sposobów segmentacji zmian skórnych. Interdyscyplinarne prace doktorantów Politechniki Lubelskiej 2019, 33-45.

[25] Michalska M.: Wykorzystanie segmentacji przez progowanie w wykrywaniu czerniaka skóry. Wybrane zagadnienia z zakresu elektrotechniki, inżynierii biomedycznej i budownictwa prace doktorantów Politechniki Lubelskiej 2019, 147-157.

[26] Michalska M., Hotra O.: Quality analysis of dermatoscopic images thresholding with malignant melanoma, Photonics Applications in Astronomy, Communications, Industry, and High-Energy Physics Experiments 2019 , $768-774$

[27] Oliveira R. B., Filho E. M., Ma Z., Papa J. P., Pereira A. S., Tavares J. M. R. S.: Computational methods for the image segmentation of pigmented skin lesions: A review. Comput. Methods Programs Biomed. 131, 2016, 127-141.

[28] Przystalski K.: Detekcja i klasyfikacja barwnikowych zmian skóry na zdjęciach wielowarstwowych [PhD thesis]. Warszawa 2014.

[29] Rosendahl C., Cameron A., McColl I., Wilkinson D.: Dermatoscopy in routine practice Chaos and Clues. Australian Family Physician 41(7), 2012, 482-487.

[30] Soyer P., Argenziano G., Zalaudek I.: Three-point checklist of dermoscopy. Dermatology 208, 2004, 27-31.

\section{M.Sc. Magdalena Michalska}

e-mail: magdalena.michalska@pollub.edu.p

Ph.D. student at the Department of Electronics and Information Technology, Lublin University of Technology. Recent graduate of Warsaw University of Technology. Her research field covers medical image processing, 3D modelling, optoelectronics, and spectrophotometry. Author of more than 10 publications.

http://orcid.org/0000-0002-0874-3285

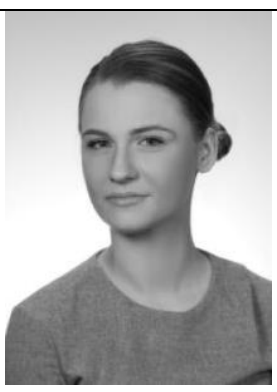

otrzymano/received: 29.03 .2020

przyjeto do drukulaccepted: 15.09 .2020 